\title{
Loopholes in Judicial System - Paves way to Violence against Women
}

\author{
*Dr.Kamalaveni, **Dr.Rupa Gunaseelan \\ *Lecturer Department of Women's Studies, Bharathiar University, Coimbatore; \\ **Associate Professor, Bharathiar School of Management and Entrepreneur Development (B.S.M.E.D.), \\ Bharathiar University, Coimbatore-641 046
}

\begin{abstract}
Crimes against women have been increasing in recent days. The deep rooted patriarchal system of the society, gender discrimination, illiteracy, increased use of drugs, alcoholism, etc are some of the factors. The PNDT Act 1994 was put forth to protect the varied interest of women. Though this law gives many explanations to protect the female fetus, the loopholes in the judicial system allow many hospitals to reveal the sex of the fetus which in turn has lead to the increase of abortion in recent days. Similarly the delay in verdict of cases has led to fear among people. Therefore care should be taken to reduce the time in giving the judgment. Hence the present study traces few loopholes in the system.
\end{abstract}

Key Words: loopholes, crimes, PNDT Act, domestic violence,

\section{Introduction}

Crimes against women have been increasing in recent days. There are humpty numbers of reason for the increase in crimes against women. The deep rooted patriarchal system of the society, gender discrimination, illiteracy, increased use of drugs, alcoholism, etc are some of the factors. Though government has enacted various legislations to protect women from violence, the loopholes in laws pave way to increase violence against women. In addition implementation of laws and access to justice has been delayed due to these loopholes in laws. Violence against women starts from womb and ends only at death. Therefore the present study is taken up to examine the loopholes in the judicial system related to women. There are various laws related to women which have loopholes.

\section{Methodology}

The present study is descriptive in nature and based on survey method. The study involves secondary data. Secondary data were collected from journals, books, newspapers, and websites.

\section{Gap in Judicial System leads to declined sex ratio}

The advent of new reproductive technologies helped women to move form private sphere to public sphere. At the same time these technologies have imbalanced the sex ratio which is a form of crime against girl child. The PNDT Act 1994 was put forth to protect the varied interest of women.

Suggestions for prenatal diagnosis and abortion became common. Various organizations working for the welfare and upliftment of women raised objections and organized demonstrations against the practice of preconception and prenatal diagnosis and demanded for a law in this regard. Hence the matter was discussed in the parliament and prenatal diagnostic technique bill was passed in both houses. After receiving the assent of the president of India it become the law in 1994. Though this law gives many explanations to protect the female fetus, the loopholes in the judicial system allow many hospitals to reveal the sex of the fetus which in turn has lead to the increase of abortion in recent days. A study done by UNFPA in the year 2000 shows statistical data as follows.

Table

\begin{tabular}{|c|c|c|}
\hline S.No & Year & Abortion Rate \\
\hline 1. & 1989 & 10.9 \\
\hline 2. & 1994 & 12.6 \\
\hline 3. & 1998 & 17.6 \\
\hline
\end{tabular}

*Source: Current Status of abortion in India" Consortium on National Consensus for Medical Abortion in India

According to the consortium on National Consensus for Medical Abortion in India, every year an average of about eleven million abortions take place annually. Most abortion -related maternal deaths are attributable to illegal abortions. 


\begin{tabular}{|c|c|c|}
\hline S.No & Year & Abortion Rate \\
\hline 1. & 1972 & 24,300 \\
\hline 2. & 1975 & $2,14,197$ \\
\hline 3. & 1980 & $3,88,405$ \\
\hline 4. & 1985 & $5,83,704$ \\
\hline 5. & 1990 & $5,81,215$ \\
\hline 6. & 1995 & $5,70,914$ \\
\hline 7. & 2000 & $7,23,142$ \\
\hline 8. & 2003 & $12,29,937$ \\
\hline 9. & 2007 & $18,95,721$ \\
\hline 10 & 2012 & $25,29,979$ \\
\hline
\end{tabular}

*Source: Current Status of abortion in India" Consortium on National Consensus for Medical Abortion in India

\section{Weakness in Justice Delivery System leads to increased violence against women}

The NLSIU pointed out that several women in the examined cases had committed suicide following act of violence, an issue that is rarely addressed in the judicial system. It was evident from the findings that domestic violence and compromise under domestic pressures have causal link with abandonment of cases. This is an issue that can be further examined to understand the psychological pressures of the trial process on the victims $^{2}$.

- Standard of proof in criminal cases is very high

- Lack of medical evidence

- Personal experience of judiciary and corruption

- Almost the cases takes six to ten months to bring the case for trial

- Long pending cases resulting in almost 4-5 years for judgment

- Most women cases are tried out in open courts

- Due to prolonged trials most victims go hostile

- Cross examination of women victims is more humiliating than crime itself

- Often parents of women victim go hostile under social pressure in dowry death cases

- Often lawyers /judge indulge in sexual abuse of women clients

\section{Fear of formal legal system has lead to culture of silence}

The formal legal system in India bears fear in the minds of Indian women. Many times the so called formal legal system itself causes violence against women which reveals the deep rooted patriarchal mind set. Most of crimes carried out on women go unrecognized due to fear of police, corruption, political pressure, caste bearings etc. women continue to bear atrocities at home to keep her family intact. Police often fail to register complaints on domestic violence and often treat it as a family matter. In rape cases the condition of women goes still worst in such way that it degrades and humiliates her to register the cases and go through the trial process at court. Most witnesses become hostile in such cases due to long periods, threat, monetary benefits offered by the accused. Many times court becomes insensitive since all crimes against women must be proved beyond reasonable doubt. So this creates fear in women to approach formal legal system and women often approach the courts only for property disputes, divorce, wage maintenance and child custody.

\section{Conclusion}

Though the Indian judiciary system is based on the core values, morale and cultural traditions of Indian society, it has a number of loopholes which has increased crime against women. The Indian judicial system is supposed to protect the common women from lawbreakers and offenders. But in reality it has paved way to rapist and criminals due to its loopholes. The crimes carried out against women should be immediately punished under law system. The case should not be extended for long time. For example the recent Delhi rape case, the 23-year-old woman was brutally gang-raped by six men on December 16, 2012, died from her injuries two weeks later in a Singapore hospital, but the case took long time. These types of delay in the cases, allows the perpetrators to move with courage.

\section{Reference}

[1]. Kaushik P.D (2007)-, "Women Rights"Access to Justice published by Bookwell in collaboration with Rajiv Gandhi institute for contemporary Studies, New Delhi pp181-194.

[2]. "Introduction". Consortium on National Consensus for Medical Abortion in India. www.aiims.edu

[3]. "Current Status of abortion in India" Consortium on National Consensus for Medical Abortion in India. Retrieved 2008-10-11. 